\title{
Cu-exchanged heteropoly acids as efficient and reusable catalysts for preparation of 1-amidoalkyl-2-naphthols
}

\author{
HOJATOLLAH KHABAZZADEH*, KAZEM SAIDI and NEDA SEYEDI \\ Department of Chemistry, Shahid Bahonar University of Kerman 76169, Kerman, Iran \\ e-mail: hkhabazadeh@gmail.com
}

MS received 13 November 2008; revised 4 February 2009; accepted 10 February 2009

\begin{abstract}
A series of amidoalkyl naphthols were prepared in high yields using various aldehydes and urea or amides. The reaction was catalysed by $\mathrm{Cu}_{1.5} \mathrm{PMo}_{12} \mathrm{O}_{40}(\mathrm{CuPMo})$ and $\mathrm{Cu}_{1.5} \mathrm{PW}_{12} \mathrm{O}_{40}(\mathrm{CuPW})$ and conducted in molten tetrabutylammonium bromide as an ionic liquid.
\end{abstract}

Keywords. Amidoalkyl naphthol; heteropoly acid; Cu-exchanged salts; ionic liquid; tetrabutylammonium bromide.

\section{Introduction}

Compounds bearing 1,3-amino oxygenated functional groups are ubiquitous to a variety of biologically important natural products and potent drugs including a number of nucleoside antibiotics and HIV protease inhibitors, such as ritonavir and lipinavir. ${ }^{1}$ In this research, we represent an advance in the context of synthetic methodology towards mentioned class of biologically important molecules. It is noteworthy that 1-amidomethyl-2-naphthols can be converted to important biologically active 1-aminomethyl-2-naphthol derivatives by amide hydrolysis reaction. The hypotensive and bradycardiac effects of these compounds have been evaluated. ${ }^{2}$

In recent years, the use of solid acids as heterogeneous catalysts has received considerable interest in different areas of organic synthesis. ${ }^{3}$ The heterogeneous solid acids are advantageous over conventional homogeneous acid catalysts as they can be easily recovered from the reaction mixture by simple filtration and can be re-used after activation or without activation, thereby making the process economically viable. In many cases, heterogeneous catalysts can be recovered with only minor change in activity and selectivity so that they can be conveniently used in continuous flow reactions. Among various heterogeneous catalysts, heteropoly acids are most attractive, because of their unique properties such as welldefined structure, Bronsted acidity, possibility to

\footnotetext{
*For correspondence
}

modify their acid-base and redox properties by changing their chemical composition (substituted HPAs), ability to accept and release electrons, high proton mobility, etc. ${ }^{4-7}$ However, they are readily soluble in polar solvents. The solubility problem can be overcome by changing these HPAs into their corresponding salts, which are generally insoluble in polar solvents. Salts of heteropoly acids have been studied in different organic transformations under heterogeneous conditions. ${ }^{8,9}$

Multicomponent reactions (MCRs) have attracted considerable attention since they are performed without need to isolate the any intermediate during their processes; this reduces time and saves both energy and raw materials. ${ }^{10}$ They have merits over two-component reactions in several aspects including the simplicity of a one-pot procedure, possible structural variations and building up complex molecules.

The preparation of 1-amidoalkyl-2-naphthols can be carried out by multi-component condensation of aryl aldehydes, 2-naphthol and an amide in the presence of Lewis or Bronsted acid catalysts such as montmorillonite $\mathrm{K} 10$ clay, ${ }^{11} \mathrm{Ce}\left(\mathrm{SO}_{4}\right)_{2},{ }^{12}$ Iodine, ${ }^{13}$ $\mathrm{K}_{5} \mathrm{CoW}_{12} \mathrm{O}_{40} \cdot 3 \mathrm{H}_{2} \mathrm{O}{ }^{14} p$-TSA ${ }^{15}$ and Sulfamic acid. ${ }^{16}$ However, some of these catalysts suffer from the drawback of green chemistry such as prolonged reaction times, low yields, toxicity and recovery and reusability of the catalyst. Therefore, introducing clean processes and utilizing eco-friendly and green catalysts which can be simply recycled at the end of reactions have been under permanent attention. The 


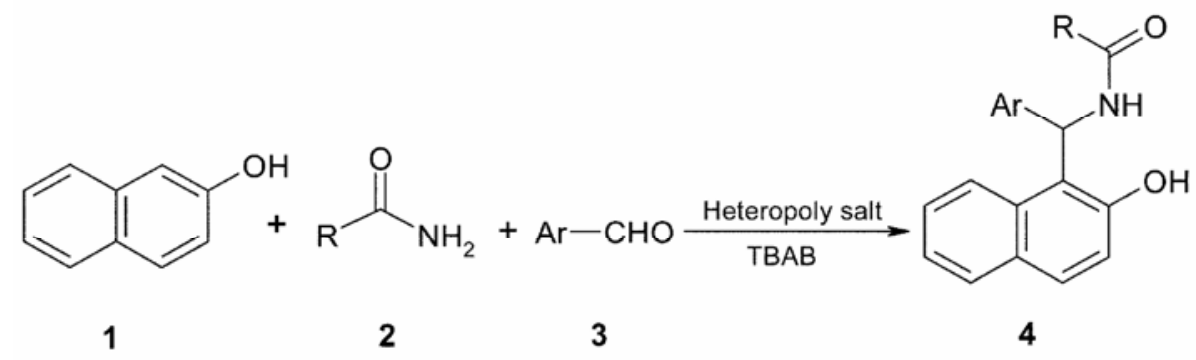

Scheme 1.

demand for environmentally benign procedure with heterogeneous and reusable catalyst ${ }^{17}$ promoted us to develop a safe alternate method for the synthesis of amidoalkyl naphthols.

A series of amidoalkyl naphthols were prepared in high yields using various aldehydes and urea or amides (scheme 1). The reaction was catalysed by $\mathrm{Cu}_{1.5} \mathrm{PMo}_{12} \mathrm{O}_{40}(\mathrm{CuPMo})$ and $\mathrm{Cu}_{1.5} \mathrm{PW}_{12} \mathrm{O}_{40}(\mathrm{CuPW})$ and conducted in molten tetrabutylammonium bromide as an ionic liquid.

\section{Experimental}

All compounds were identified by comparison of their spectral data and physical properties with those of the authentic samples. NMR spectra were recorded on a BRUKER DRX-500 AVANCE NMR spectrometer using DMSO- $d_{6}$ as solvent. Aldehydes, $\beta$-naphthol, urea, acetamide, benzamide and $\mathrm{Bu}_{4} \mathrm{NBr}$ were purchased from Merck chemical company. $\mathrm{Cu}_{1.5} \mathrm{PMo}_{12} \mathrm{O}_{40}$ and $\mathrm{Cu}_{1.5} \mathrm{PW}_{12} \mathrm{O}_{40}$ were synthesized according to the literature. ${ }^{18,19}$

\subsection{General procedure for the CuPMo catalysed} synthesis of 1-amidoalkyl-2-naphthols in molten salt media

A mixture of appropriate aldehyde $(1 \mathrm{mmol}), \beta$ naphthol $(1 \mathrm{mmol})$, amide/urea $(1 \mathrm{mmol}), \mathrm{Bu}_{4} \mathrm{NBr}$ $(1 \mathrm{mmol})$ and $\mathrm{CuPMo}(5 \mathrm{~mol} \%)$ was heated in an oil bath at $100^{\circ} \mathrm{C}$ for $90 \mathrm{~min}$. After completion of the reaction, $10 \mathrm{ml}$ of ethanol was added. The catalyst was removed by filtration and reused. The solution was poured into water and the resulting precipitate recrystallised from ethanol to give pure product 4

\subsection{Spectral data for the selected compounds}

2.2a N-[(2-Hydroxynaphthlen-1-yl)phenylmethyl] acetamide (4a): White solid; IR (KBr): 1520,
Table 1. Optimization of amounts of $\mathrm{Cu}$ exchange heteropoly salts and reaction time of benzaldehyde, $\beta$ naphthol and acetamide.

\begin{tabular}{llcc}
\hline Entry & Catalyst (mol\%) & Time (min) & Yield (\%) \\
\hline 1 & CuPMo (1) & 180 & 60 \\
2 & CuPMo (2) & 120 & 70 \\
3 & CuPMo (3) & 120 & 80 \\
4 & CuPMo (4) & 100 & 86 \\
5 & CuPMo (5) & 90 & 92 \\
6 & CuPMo (6) & 90 & 92 \\
7 & CuPW (1) & 110 & 85 \\
8 & CuPW (2) & 80 & 94 \\
9 & CuPW (3) & 80 & 94 \\
\hline
\end{tabular}

1660, 3063, 3251, $3390 \mathrm{~cm}^{-1}$. ${ }^{1} \mathrm{H}$ NMR (DMSO- $d_{6}$ ): $\delta(\mathrm{ppm})=1.99(s, 3 \mathrm{H}), 7.15-7.37(m, 9 \mathrm{H}), 7.76-$ $7.82(m, 3 \mathrm{H}), \quad 8.45 \quad(d, \quad J=8.32 \mathrm{~Hz}, 1 \mathrm{H}), \quad 9.99$ $(s, 1 \mathrm{H})$.

$2.2 \mathrm{~b} \quad \mathrm{~N}$-[(2-Hydroxy-naphthalen-1-yl)-p-tolylmethyl]-acetamide (4c): White solid; IR (KBr): 1519, 1659, 2970, 3063, $3391 \mathrm{~cm}^{-1}$. ${ }^{1} \mathrm{H}$ NMR $\left(\right.$ DMSO- $\left.d_{6}\right): \delta(\mathrm{ppm})=1.99(s, 3 \mathrm{H}), 2.23(s, 3 \mathrm{H})$, 7.06-7.36 (m, 8H), 7.75-7.85 (m, 3H), 8.42 (d, $J=8 \cdot 12 \mathrm{~Hz}, 1 \mathrm{H}), 9.97(s, 1 \mathrm{H})$.

\section{2c N-[(2-Hydroxy-naphthalen-1-yl)-(4-nitro-}

phenyl)-methyl]-acetamide (4d): Pale yellow solid; IR (KBr): 1520, 1660, 2975, 3080, $3380 \mathrm{~cm}^{-1}$. ${ }^{1} \mathrm{H}$ NMR (DMSO- $\left.d_{6}\right): \delta(\mathrm{ppm})=2 \cdot 03(s, 3 \mathrm{H}), 7 \cdot 19-$ $7.24(m, 4 \mathrm{H}), 7.41(d, J=7.1 \mathrm{~Hz}, 2 \mathrm{H}), 7.80(m, 3 \mathrm{H})$, $8.14(d, J=7.2 \mathrm{~Hz}, 2 \mathrm{H}), 8.60(d, J=6.15 \mathrm{~Hz}, 1 \mathrm{H})$, $10 \cdot 12(s, 1 \mathrm{H})$.

\section{Results and discussion}

Benzaldehyde was selected as a representative aldehyde along with of $\beta$-naphthol, acetamide and $\mathrm{CuPMo}$ or $\mathrm{CuPW}$ were reacted in presence of tetrabutylammonium bromide at $100^{\circ} \mathrm{C}$ in order to 
Table 2. Preparation of 1-amidoalkyl-2-naphthols.

\begin{tabular}{|c|c|c|c|c|c|c|}
\hline \multirow[b]{2}{*}{ Entry } & \multirow[b]{2}{*}{$\mathrm{Ar}$} & \multirow[b]{2}{*}{ Urea/amide } & \multirow[b]{2}{*}{ Product 4} & \multicolumn{2}{|c|}{ Yield (\%) } & \multirow[b]{2}{*}{$m p^{\mathrm{ref}}$} \\
\hline & & & & $\mathrm{CuPW}^{\mathrm{a}}$ & $\mathrm{CuPMo}^{\mathrm{b}}$ & \\
\hline 1 & $\mathrm{C}_{6} \mathrm{H}_{5}$ & $\mathrm{CH}_{3} \mathrm{CONH}_{2}$ & $4 a$ & 94 & 92 & $238-240^{11}$ \\
\hline 2 & $4-\mathrm{CH}_{3} \mathrm{O}-\mathrm{C}_{6} \mathrm{H}_{4}$ & $\mathrm{CH}_{3} \mathrm{CONH}_{2}$ & $4 b$ & 82 & 75 & $180-182^{20}$ \\
\hline 3 & $4-\mathrm{CH}_{3}-\mathrm{C}_{6} \mathrm{H}_{4}$ & $\mathrm{CH}_{3} \mathrm{CONH}_{2}$ & $4 c$ & 88 & 85 & $220-223^{20}$ \\
\hline 4 & $4-\mathrm{Cl}-\mathrm{C}_{6} \mathrm{H}_{4}$ & $\mathrm{CH}_{3} \mathrm{CONH}_{2}$ & $4 d$ & 78 & 76 & $224-226^{20}$ \\
\hline 5 & $4-\mathrm{NO}_{2}-\mathrm{C}_{6} \mathrm{H}_{4}$ & $\mathrm{CH}_{3} \mathrm{CONH}_{2}$ & $4 e$ & 92 & 92 & $245-246^{20}$ \\
\hline 6 & $3-\mathrm{NO}_{2}-\mathrm{C}_{6} \mathrm{H}_{4}$ & $\mathrm{CH}_{3} \mathrm{CONH}_{2}$ & $4 f$ & 90 & 87 & $238-240^{20}$ \\
\hline 7 & $2,4-\mathrm{Di}-\mathrm{Cl}-\mathrm{C}_{6} \mathrm{H}_{3}$ & $\mathrm{CH}_{3} \mathrm{CONH}_{2}$ & $4 \mathrm{~g}$ & 84 & 80 & $225-228^{11}$ \\
\hline 8 & $2-\mathrm{Cl}-\mathrm{C}_{6} \mathrm{H}_{4}$ & $\mathrm{CH}_{3} \mathrm{CONH}_{2}$ & $4 \mathrm{~h}$ & 75 & 70 & $196-198^{16}$ \\
\hline 9 & $2-\mathrm{CH}_{3}-\mathrm{C}_{6} \mathrm{H}_{4}$ & $\mathrm{CH}_{3} \mathrm{CONH}_{2}$ & $4 i$ & 74 & 70 & $200-201^{20}$ \\
\hline 10 & $\mathrm{C}_{6} \mathrm{H}_{5}$ & $\mathrm{NH}_{2} \mathrm{CONH}_{2}$ & $4 \mathbf{j}$ & 95 & 93 & $170-173^{16}$ \\
\hline 11 & $4-\mathrm{Cl}-\mathrm{C}_{6} \mathrm{H}_{4}$ & $\mathrm{NH}_{2} \mathrm{CONH}_{2}$ & $4 \mathbf{k}$ & 86 & 82 & $166-168^{16}$ \\
\hline 12 & $3-\mathrm{NO}_{2}-\mathrm{C}_{6} \mathrm{H}_{4}$ & $\mathrm{NH}_{2} \mathrm{CONH}_{2}$ & 41 & 92 & 90 & $186-188^{16}$ \\
\hline 13 & $\mathrm{C}_{6} \mathrm{H}_{5}$ & $\mathrm{PhCONH}_{2}$ & 40 & 85 & 82 & $233-236^{16}$ \\
\hline 14 & $4-\mathrm{Cl}-\mathrm{C}_{6} \mathrm{H}_{4}$ & $\mathrm{PhCONH}_{2}$ & $4 p$ & 85 & 80 & $175-177^{16}$ \\
\hline 15 & $4-\mathrm{CH}_{3}-\mathrm{C}_{6} \mathrm{H}_{4}$ & $\mathrm{PhCONH}_{2}$ & $4 q$ & 82 & 76 & $190-193^{16}$ \\
\hline 16 & $3-\mathrm{NO}_{2}-\mathrm{C}_{6} \mathrm{H}_{4}$ & $\mathrm{PhCONH}_{2}$ & $4 r$ & 85 & 80 & $214-216^{16}$ \\
\hline
\end{tabular}

${ }^{\mathrm{a}}$ Reaction conditions: aldehyde $(1 \mathrm{mmol}), \beta$-naphthol $(1 \mathrm{mmol})$, amide/urea $(1 \mathrm{mmol}), \mathrm{Bu}_{4} \mathrm{NBr}(1 \mathrm{mmol})$ and $\mathrm{CuPW}$ ( $2 \mathrm{~mol} \%$ )

${ }^{b}$ Reaction conditions: aldehyde ( $\left.1 \mathrm{mmol}\right), \beta$-naphthol $(1 \mathrm{mmol})$, amide/urea ( $\left.1 \mathrm{mmol}\right), \mathrm{Bu}_{4} \mathrm{NBr}(1 \mathrm{mmol})$ and CuPMo (5 $\mathrm{mol} \%)$

Table 3. Re-usability of catalysts.

\begin{tabular}{llcc}
\hline Entry & Catalyst & Number of recycles & Yield (\%) \\
\hline 1 & CuPMo & Fresh & 92 \\
2 & CuPMo & 1 & 88 \\
3 & CuPMo & 2 & 85 \\
4 & CuPW & Fresh & 94 \\
5 & CuPW & 1 & 90 \\
6 & CuPW & 2 & 88 \\
\hline
\end{tabular}

optimize the reaction conditions. As can be seen from table 1 , it was found that the reaction in the presence of $5 \mathrm{~mol} \%$ of $\mathrm{CuPMo}$ and $2 \mathrm{~mol} \%$ of $\mathrm{CuPW}$ needs shorter reaction time and gives best yields. Using higher amounts of catalysts did not have considerable effect on the yield and reaction time. So the best condition was that the reaction was catalysed by $5 \mathrm{~mol} \%$ of CuPMo and $2 \mathrm{~mol} \%$ of CuPW in 90 and 80 minutes respectively.

In order to evaluate the generality of the process, several examples illustrating the present method for the synthesis of amidoalkyl naphthols $\mathbf{4}$ were studied (table 2). The reaction of $\beta$-naphthol 2 with various aromatic aldehydes bearing electron withdrawing groups (such as nitro and halide), electron releasing groups (methyl and methoxy groups) and acetamide, benzamide or urea was carried out in the presence of
$\mathrm{CuPMo}$ and $\mathrm{CuPW}$ as catalyst. In all these reactions, clean and complete conversion was obtained leading to the corresponding amidoalkyl naphthols. The yields obtained were good to excellent without formation of any side products such as di-benzoxanthenes, which are normally observed under the influence of strong acids.

The reusability of the catalyst was also examined by treating benzaldehyde with $\beta$-naphthol and acetamide in the presence of $5 \mathrm{~mol} \%$ and $2 \mathrm{~mol} \%$ of $\mathrm{CuPMo}$ and $\mathrm{CuPW}$ for three consecutive reactions respectively. The reactions proceed smoothly with a few decrease in the yield and this result indicates that the catalyst can be reused without significant loss of activity (table 3 ).

To show the merit of the present work in comparison with reported results in the literature, we compared results of $\mathrm{CuPMo}$ and $\mathrm{CuPW}$ with montmorillonite $\mathrm{K} 10$ clay, ${ }^{11}$ iodine, ${ }^{13}$ and $\mathrm{K}_{5} \mathrm{CoW}_{12} \mathrm{O}_{40}$. $3 \mathrm{H}_{2} \mathrm{O}^{14}$ in the synthesis of 1-amidomethyl-2naphthol derivatives. As shown in table 4, CuPMo and $\mathrm{CuPW}$ can act as effective catalysts with respect to reaction times and yields of the obtained products. Thus, the present protocol with $\mathrm{Cu}$-exchanged heteropoly acids catalyst is convincingly superior to the previous reported catalytic methods.

As reported in the literatures, ${ }^{13,15}$ the reaction of $\beta$-naphthol with aromatic aldehydes in the presence 
Table 4. Comparison of the results of synthesis of 1-amidoalkyl-2-naphthols in the presence of CuPMo and CuPW in molten salt media with the literature.

\begin{tabular}{|c|c|c|c|c|c|c|}
\hline Entry & Amide & Aldehyde & Catalyst & Mol ratio of catalyst & Time (min) & Yield (\%) \\
\hline 1 & $\mathrm{CH}_{3} \mathrm{CONH}_{2}$ & & $\begin{array}{l}\mathrm{K} 10 \\
\mathrm{I}_{2} \\
\mathrm{~K}_{5} \mathrm{CoW}_{12} \mathrm{O}_{40} \cdot 3 \mathrm{H}_{2} \mathrm{O} \\
\mathrm{Cu}_{1.5} \mathrm{PW}_{12} \mathrm{O}_{40} \\
\mathrm{Cu}_{1.5} \mathrm{PMo}_{12} \mathrm{O}_{40}\end{array}$ & $\begin{array}{l}0 \cdot 1 \mathrm{~g} \\
5 \mathrm{~mol} \% \\
1 \mathrm{~mol} \% \\
2 \mathrm{~mol} \% \\
5 \mathrm{~mol} \%\end{array}$ & $\begin{array}{r}90 \\
330 \\
120 \\
80 \\
90\end{array}$ & $\begin{array}{l}89 \\
85 \\
90 \\
94 \\
92\end{array}$ \\
\hline 2 & $\mathrm{NH}_{2} \mathrm{CONH}_{2}$ & & $\begin{array}{l}\mathrm{K} 10 \\
\mathrm{I}_{2} \\
\mathrm{~K}_{5} \mathrm{CoW}_{12} \mathrm{O}_{40} \cdot 3 \mathrm{H}_{2} \mathrm{O} \\
\mathrm{Cu}_{1.5} \mathrm{PW}_{12} \mathrm{O}_{40} \\
\mathrm{Cu}_{1.5} \mathrm{PMo}_{12} \mathrm{O}_{40}\end{array}$ & $\begin{array}{l}0.1 \mathrm{~g} \\
5 \mathrm{~mol} \% \\
1 \mathrm{~mol} \% \\
2 \mathrm{~mol} \% \\
5 \mathrm{~mol} \%\end{array}$ & $\begin{array}{r}90 \\
270 \\
180 \\
80 \\
90\end{array}$ & $\begin{array}{l}86 \\
87 \\
80 \\
95 \\
93\end{array}$ \\
\hline
\end{tabular}

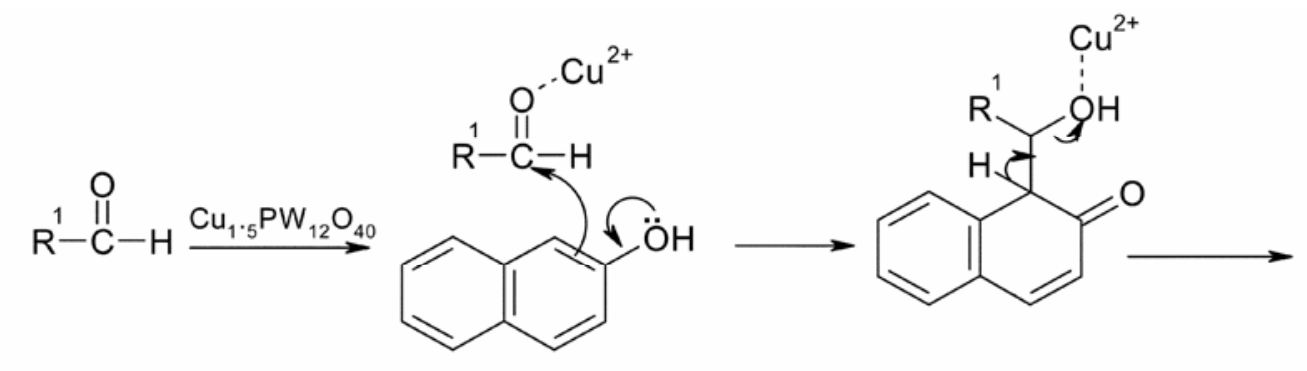

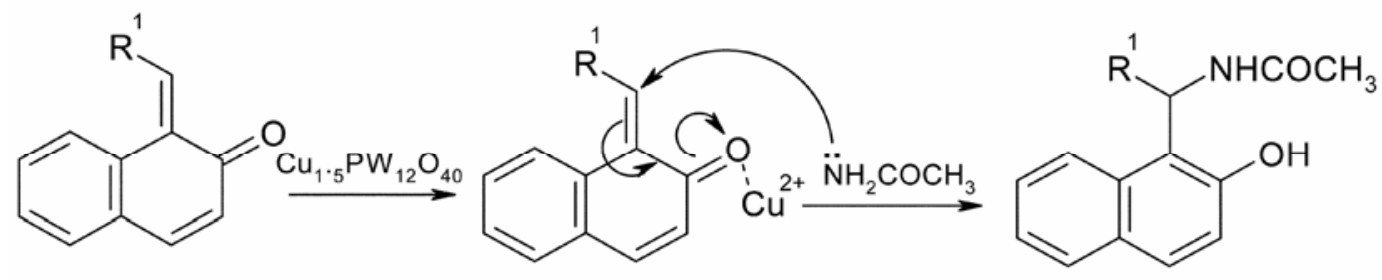

Scheme 2.

of acid catalyst is known to give ortho-quinone methides (O-QMs). The same O-QMs, generated in-situ, have been reacted with acetamide to form 1-amidoalkyl-2-naphthol derivatives. A reasonable explanation for this result can be given by considering the nucleophilic addition to O-QM intermediate favourable via conjugate addition on the $\alpha, \beta$ unsaturated carbonyl group and finally this intermediate will aromatize to produce the final aromatic compound. A plausible way of formation of $\mathbf{4}$ is shown in scheme 2 .

\section{Conclusion}

In conclusion, we have developed a very simple and efficient method for the high-yielding synthesis of amidoalkyl naphthols by one-pot three-component coupling of $\beta$-naphthol, various aromatic aldehydes and urea or amides using $\mathrm{Cu}_{1.5} \mathrm{PMo}_{12} \mathrm{O}_{40}$ and $\mathrm{Cu}_{1.5} \mathrm{PW}_{12} \mathrm{O}_{40}$ as heterogeneous acid catalysts which can be reused without significant loss of activity. The reaction was conducted in molten tetrabutylammonium bromide as a cost effective ionic liquid.

\section{Acknowledgements}

We gratefully acknowledge the financial support from the Research Council of Shahid Bahonar University of Kerman, Iran.

\section{References}

1. Wang Y F, Izawa T, Kobayashi S and Ohno M 1982 J. Am. Chem. Soc. 1046465

2. Shen A Y, Chen C L and Lin C 1992 Chin. J. Physiol. 3545 
3. Seitz W J, Saha A K and Hossain M M 1993 Organometallics 122604

4. Kozhevnikov I V 1998 Chem. Rev. 98171.

5. Okuhara T, Mizuno N and Misono M 2001 Appl. Catal. A: Gen. 22263

6. Clark J H 2002 Acc. Chem. Res. 35791

7. Fukuda T and Katsuki T 1995 Synlett 825

8. Imada Y, Yuassa M, Nakamura I and Murahashi S I 1994 J. Org. Chem. 592282

9. Reddy K M, Babu N S, Suryanarayana I, Prasad P S S and Lingaiah N 2006 Tetrahedron Lett. 477563

10. Nagawade R R and Shinde D B 2007 Acta Chim. Slov. 54642

11. Kantevari S, Vuppalapati S V N and Nagarapu L 2007 Catal. Commun. 81857

12. Selvam N P and Perumal P T 2006 Tetrahedron Lett. 477481
13. Das B, Laxminarayana K, Ravikanth B and Rao B R 2007 J. Mol. Catal. A: Chem. 261180

14. Nagarapu L, Baseeruddin M, Apuri S and Kantevari S 2007 Catal. Commun. 81729

15. Khodaei M M, Khosropour A R and Moghanian H 2006 Synlett 916

16. Patil S B, Singh P R, Surpur M P and Samant S D 2007 Ultrason. Sonochem. 14515

17. Salehi P, Khodaei M M, Zolfigol M A and Zeinoldini S 2003 Synth. Commun. 331367

18. Allaoui L A and Aouissi A 2006 J. Mol. Catal. A: Chem. 259281

19. Yadav J S, Subba Reddy B V, Purnima K V, Nagaiah $\mathrm{K}$ and Lingaiah N 2006 J. Mol. Catal. A: Chem. 285 36

20. Shaterian H R and Yarahmadi H 2008 Arkivoc ii 105 